OPEN $\bigcirc$ ACCESS

ISSN1927-6648

International Journal of

Marine Science

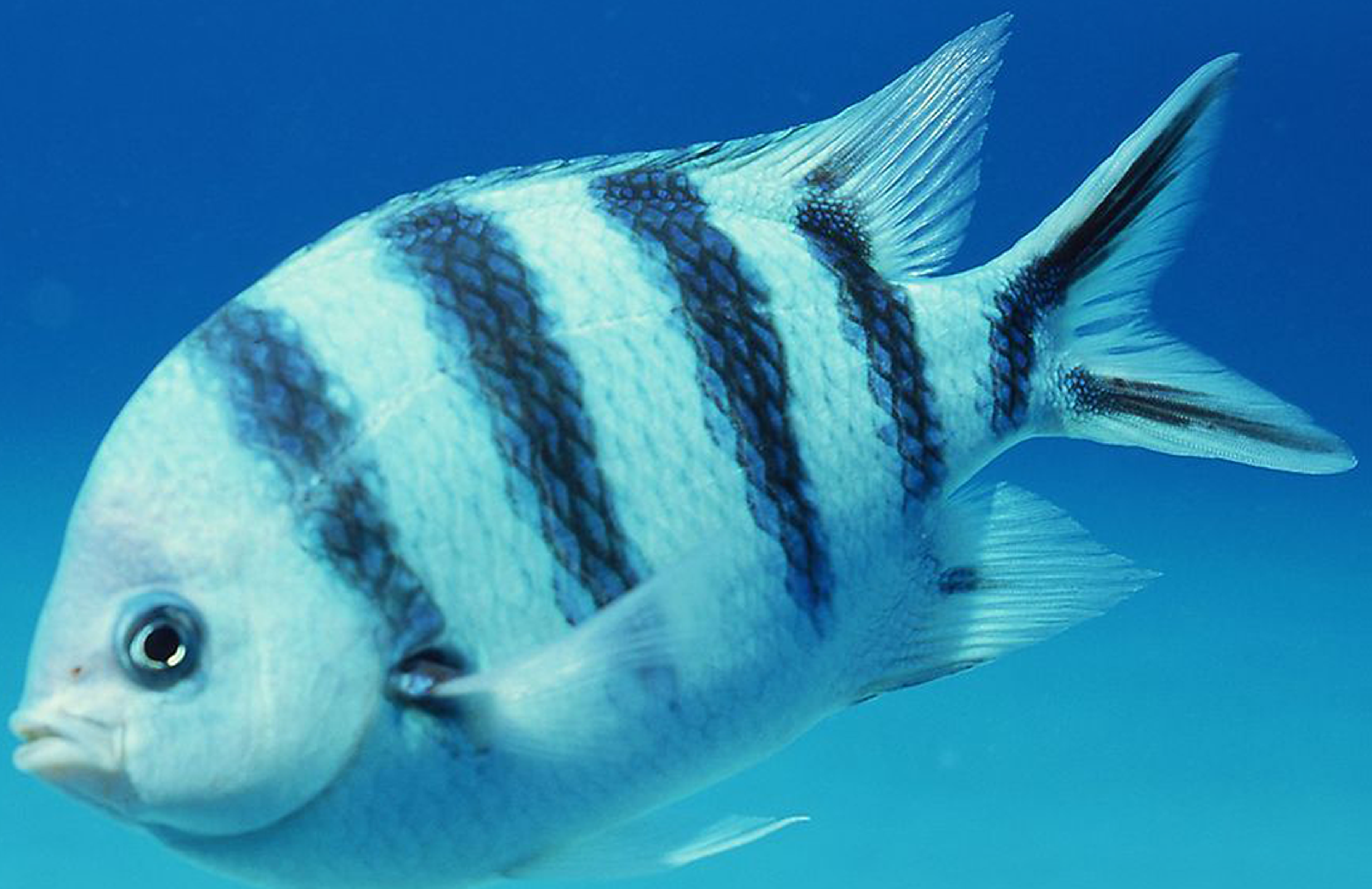




\section{Publisher}

Sophia Publishing Group

\section{Edited by}

Editorial Team of International Journal of Marine Science

Email: edit@ijms.sophiapublisher.com

Website: http://ijms.sophiapublisher.com

Address:

11388 Stevenston Hwy,

PO Box 96016,

Richmond, V7A 5J5, British Columbia

Canada

International Journal of Marine Science (ISSN 1927-6648) is an open access, peer reviewed journal published online by BioPublisher.

The journal publishes all the latest and outstanding research articles, letters and reviews in all areas of marine science, the range of topics containing the advancement of scientific and engineering knowledge regarding the sea; from chemical and physical to biological oceanography, from estuaries and coastal waters to the open ocean; as well as including fisheries, socio-economic science, co-management, ecosystems and other topical advisory subjects.

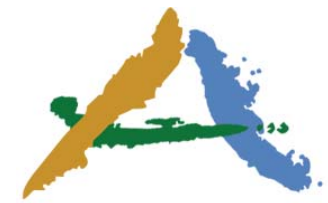

BioPublisher $^{\odot}$
BioPublisher, operated by Sophia Publishing Group (SPG), is an
international Open Access publishing platform that publishes scientific
journals in the field of life science. Sophia Publishing Group (SPG),
founded in British Columbia of Canada, is a multilingual publisher.

\section{Open Access}

All the articles published in International Journal of Marine Science are Open Access, and are distributed under the terms of the Creative Commons Attribution License, which permits unrestricted use, distribution, and reproduction in any medium, provided the original work is properly cited.

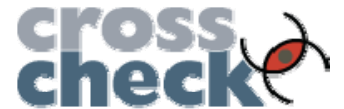

BioPublisher uses CrossCheck service to identify academic plagiarism through the world's leading plagiarism prevention tool, iParadigms, and to protect the original authors' copyrights. 


\section{Latest Content}

Influences of Environmental Factors on Fish Assemblage in the Tropical Estuary of South West Coast of India, A

Case Study of Kodungallur-Azhikode Estuary

4-16

P.R. Jayachandran, S. Bijoy Nandan, O.K. Sreedevi, V.F. Sanu

The Dynamic of Embankment Width Change at the Coastal Area of Pangkep District, South Sulawesi Province, $\underline{\text { Indonesia }}$

Andi Gusti Tantu, Ahmad Mustafa, Dahlifa, Andi Rezky Puspita Ayu

Barrier and Platform Reefs of the Vietnamese Coast of the South China Sea

Yuri Latypov

Biodiesel Fuel Production from Marine Microalgae Isochrysis galbana, Pavlova lutheri, Dunaliella salina and Measurement of its Viscosity and Density

T. Sujin Jeba Kumar, C.K. Balavigneswaran, K.P. Srinivasakumar

Integrating Anthropogenic and Climatic Factors in the Assessment of the Caribbean Spiny Lobster (Panulirus argus) in Cuba: Implications for Fishery Management

Rafael Puga, Roberto Piñeiro, Romina Alzugaray, Lisset Susana Cobas, María Estela de León, Ofelia Morales

Variability in the Tropical Southwest Indian Ocean and Influence on Southern African Climate

Mark R. Jury

$\underline{\text { Sea Surface Warming and its Implications for Harmful Algal Blooms off Oman }}$

Y.V.B. Sarma, Khalid Al-Hashmi, Sharon L. Smith

Carbon Partitioning and Allometric Relationships between Stem Diameter and Total Organic Carbon (TOC) in Plant Components of Bruquiera gymnorrhiza (L.) Lamk. And Lumnitzera racemosa Willd. in a Microtidal Basin Estuary in Sri Lanka

K.A.R.S. Perera, M.D. Amarasinghe

Environmental Influences on Agulhas Fish Catch

Mark R. Jury

Mapping the Under Water Habitat Related to their Bathymetry using Worldview-2 (wv-2) Coastal, Yellow, Rededge, Nir-2 Satellite Imagery in Gulf of Mannar to Conserve the Marine Resource 91-97

R. Uma Maheswari

Food and Feeding Habits of the Mudskipper, Boleophthalmus boddarti (Pallas, 1770) from Pichavaram Mangroves, Southeast Coast of India 


\section{Latest Content (Continued)}

Concentration of Polycyclic Aromatic Hydrocarbon (PAHs) in the Sediments and Milkfish (Chanos chanos, Forsk) at Marunda and Blanakan Ponds, Indonesia

$105-110$

Noverita Dian Takarina, Sharfina Tammy Aryanti, Mohammad Agung Nugraha

Spatial Patterns in Diversity and Distribution of Benthic Molluscs in a Weak Tidal Tropical Lagoon

R.E. Uwadiae

Microzooplankton Grazing Impact on Phytoplankton Blooms in the Coastal Seawater of the Southern Crimea (Black Sea)

L.V. Stelmakh

Spatial and Temporal Variation of Total Nitrogen and Total Phosphorus in Major River Systems of Sundarbans Mangrove Forest, Bangladesh

$128-134$

S.M. Bazlur Rahaman, Md. Sharif Hasan Sohag, Alokesh Kumar Ghosh, Sudhin Kumar Biswas, Lipton Sarder, Joyanta Bir, Shahjahan Siraj Opu

Effect of Temperature and Nutrient Limitation on the Growth and Lipid Content of Three Selected Microalgae (Dunaliella tertiolecta, Nannochloropsis sp. and Scenedesmus sp.) for Biodiesel Production

135-144

Nita Rukminasari

Long-term Changes in Sea Surface Temperature at Selected Locations in the Sea of Oman and the Arabian Sea off $\underline{\text { Oman }}$ $145-150$

Y.V.B. Sarma, Anesh Govender, Ebenezer S. Nyadjro, Sergey Piontkovski

$\underline{\text { Immunomodulating Properties of Bioactive Compounds Present in Aurora globostellata }}$

K. Chairman, M. Jeyamala, S. Sankar, A. Murugan, A.J.A. Ranjit Singh

Can the Marine Ecosystem of a Posidonia oceanica Back-reef React and Defend Itself against the Spread of Caulerpa racemosa var. cylindracea?

158-165

Mauro Lenzi, Francesca Birardi, Maria Grazia Finoia

The First Record of Three Cymothoid Isopods from Red Sea Fishes, Yemeni Coastal Waters

A.B. Zubaidy, F.T. Mhaisen

Temporal and Spatial Variation of Sand Dunes, the Caspian Sea

Homayoun Khoshravan, Seidmasoumeh Banihashemi, Mahdieh Shapouri 


\section{Latest Content (Continued)}

Conservation and Management of Tuna Fisheries in the Indian Ocean and Indian EEZ

P. Satheeshkumar, N.G.K. Pillai

Census and Phenology of Breeding Waterbirds on the Islands of Khan, Tahmadon, Om-Al-Gorm and Nakhiloo in the Persian Gulf, Iran

$193-200$

Behrouz Behrouzi-Rad

Levels of Organochlorines Contaminants on Fish Species from Coastal Area in the Southeastern Brazil

Aldo Pacheco Ferreira

Bioaccumulation of $\mathrm{Pb}, \mathrm{Cd}, \mathrm{Cu}$, and $\mathrm{Cr}$ by Porphyridium cruentum (S.F. Gray) Nägeli

Tri Retnaningsih Soeprobowati, Riche Hariyati

Fish Distribution in Fauna Data in Lagoon of Aveiro (North Portugal): a Comparative Analysis between 1758 and the Present-An Interdisciplinary Case Study

M.R. Bastos, A. Vidal, U.M. Azeiteiro, J.A. Dias

Criteria for Incorporating the Guidelines of the Integrated Coastal Zone Management (ICZM) in Territorial Land Use Planning: Study Case for the Colombian Pacific Coastal Area

Ángela López Rodrí guez, Paula Cristina Sierra Correa, Pilar Lozano-Rivera

Geochemical Fractionation of Copper (Cu), Lead (Pb), and Zinc $(\mathrm{Zn})$ in Sediment and their Correlations with Concentrations in Bivalve Mollusc Anadara indica from Coastal Area of Banten Province, Indonesia

Noverita Dian Takarina, Dietriech G Bengen, Harpasis S Sanusi, Etty Riani

Construction of Scenarios: Planning and Sustainable Development in the Northern Coastal Area of Camagüey Province, Cuba

Ernesto Figueredo Castellanos, María Elena Zequeira, Pedro Morales, Mayra González, José Plasencia, Alfredo León

Caspian Rapid Sea Level Changing Impact on Estuaries Morphodynamic Deformation

Homayoun Khoshravan, Masoumeh Banihashemi

Performance Assessment of Lokoja Confluence Beach as a Tourist Site in Kogi State, Nigeria

Samuel Oluwaseyi Olorunfemi, Emmanuel Adebayo Adewunmi

Representation of Coastal Upwelling and Environmental Interactions in the Southern Benguela in Satellite Era

Reanalysis

267-277

Mark R. Jury 


\section{Latest Content (Continued)}

Fishermen Community Economic Empowerment through Joint Development Business Group in Cirebon City

Liliek Soeprijadi, Endang Yuli, Edi Susilo, Rudianto

A Stable Isotope Study of the Relationship between Coral Tissues and Zooxanthellae in a Seasonal Tropical Environment of East Kalimantan, Indonesia

Handoko Adi Susanto, Makoto Komoda, Masaaki Yoneda, Akihiro Kano, Mutsunori Tokeshi, Hiroko Koike

Comparative Ultrastructural and Biochemical Studies of Four Demosponges from Gulf of Mannar, India

Ramjee Pallela, Venkateswara Rao Janapala

Mass Mortality of Porites Corals on Northern Persian Gulf Reefs due to Sediment-Microbial Interactions

Javid Kavousi, Parviz Tavakoli-Kolour, Abbas Barkhordari, Arezoo Bahrami

Waterbirds Population, Species Diversity and Similarity Fluctuation in Relation to Water Pollution in Zangi and Ahmadi Coastal Wetlands in Khore Mosa, Iran

311-318

Behrouz Behrouzi-Rad

Low-input Modified Extensive Shrimp Culture Systems for Penaeus monodon Restrain Vibriosis 319-332 Sheryl Oliveira Fernandes, R.A. Sreepada, Shantanu S. Kulkarni, Sheetal V. Karekar, Resha R. Shirodkar, Christian Vogelsang, P.A. Lokabharathi

Tracking the Response of Phytoplankton following Gyttja Disturbance: a Mesocosm Field Study in Myall Lakes, New South Wales, Australia

Nita Rukminasari

Birds Observation and Nest Count of Crab Plover Dromas ardeola, Western Reef Heron Egretta gularis and four Tern species on Ghaber Nakhoda Island (Persian Gulf) in 2003 and 2012

Behrouz Behrouzi-Rad

Coupling of Shoreline Erosion and Biodiversity Loss: Examples from the Black Sea

N.V. Shadrin

The Aqaba Marine Protected Area-Integration of Marine Science and Resource Management in the Gulf of Aqaba-Red Sea $361-367$

Mohammad Al-Zibdah 


\section{Latest Content (Continued)}

Ecomorphological Analyses of Marine Mollusks' Shell Thickness of Rapana venosa (VALENCIENNES, 1846) (Gastropoda: Muricidae)

Igor P. Bondarev

Integration as a Significance Factor in Effective Coastal Management: Egypt as a Case Study

$389-401$

Hossam Samir Ibrahim, Safaa A. Ghoneim

$\underline{\text { Sex Ratio Variation of the Omani Indian Oil Sardine Sardinella longiceps (Valenciennes, 1847) }}$

$402-407$

Saud Musallam Al-Jufaili

A Review of the Green Mussel Perna viridis Fishery of South West Coast of India

408-416

P. Laxmilatha 


\title{
A Review of the Green Mussel Perna viridis Fishery of South West Coast of India
}

\author{
P. Laxmilatha \\ Central Marine Fisheries Research Institute, P. B. No. 1603, Ernakulam North P.O., Cochin 682 018, Kerala, India \\ DCorresponding author email: laxmil@yahoo.com \\ International Journal of Marine Science, 2013, Vol.3, No.48 doi: 10.5376/ijms.2013.03.0048 \\ Received: 03 Oct., 2013 \\ Accepted: 06 Nov., 2013 \\ Published: 14 Nov., 2013
}

Copyright @ 2013 Laxmilatha, This is an open access article published under the terms of the Creative Commons Attribution License, which permits unrestricted use, distribution, and reproduction in any medium, provided the original work is properly cited.

Preferred citation for this article:

Laxmilatha, 2013, A Review of the Green Mussel Perna viridis Fishery of South West Coast of India, International Journal of Marine Science, Vol.3, No.48 408-416 (doi: 10.5376/ijms.2013.03.0048)

\begin{abstract}
The green mussel, Perna viridis (Linnaeus1758) (Bivalvia, Mytilidae) is a commercially important species in India. Estimated total production from the mussel beds along the Malabar Coast during 1996-2008 was 89,593 $\mathrm{t}$ and the average annual production was 7,466 t. The total effort was 1,583,639 and the average annual catch per unit of effort was 56.6. Among the eight major mussel landing centres, Chaliyam (28\%) recorded the highest production during 2003-2008 followed by Thalasseri / Thalayi and Moodadi / Thikkodi (19\%), and Elathur / Kollam (9\%). Effort was also highest at Chaliyam (24\%) followed by Thalasseri / Thalayi (20\%), Moodadi / Thikkodi (18\%). The CPUE was highest for Koduvally, (71) followed by Chaliyam (63). The average price per $100 \mathrm{Kg}$ shell-on mussel during 1996-2008 was $€ 9.9$ (INR 617). This fishery sustains the livelihood of 1,551 mussel pickers along the South West Coast. The fishery is dependent on the wild of spat fall whose annual density is influenced by the south west monsoon. The distribution, fishery and management of this fishery along the south west coast of India are described.
\end{abstract}

Keywords Green mussel; Perna viridis; Fishery; Management

\section{Introduction}

India has two species of mussels, the green mussel, Perna viridis and the brown mussel, Perna indica. The green mussel contributes substantially to the total mussel production and it is more widely distributed compared to the brown mussel. Green mussels are found along the intertidal coasts of Quilon, Alleppey, Kochi, Kozhikode (Calicut), Kannur and Kasargod districts of Kerala, a state on the south west coast of India. It is most abundant from Kozhikode - Kannur to Kasargod which is known as the mussel zone of India (Kuriakose et al., 1984) (Figure 1). Along the east coast of India, it ranges along Chilka Lake (Orissa), Vishakapatnam (Andhra Pradesh), Chennai (Tamil Nadu), and Cuddalore (Pondicherry). It is also found along Mangalore, Karwar, Goa, Ratnagiri, and in the Gulf of Kutch and the Andamans and Nicobar Islands (Jones and Alagarswami, 1973).

Bivalve exploitation plays an important role in the national economy of many countries (Vakily, 1992). Although limited in its geographical distribution, the green mussel has been of potential interest to several investigators. The genus Perna has been described by

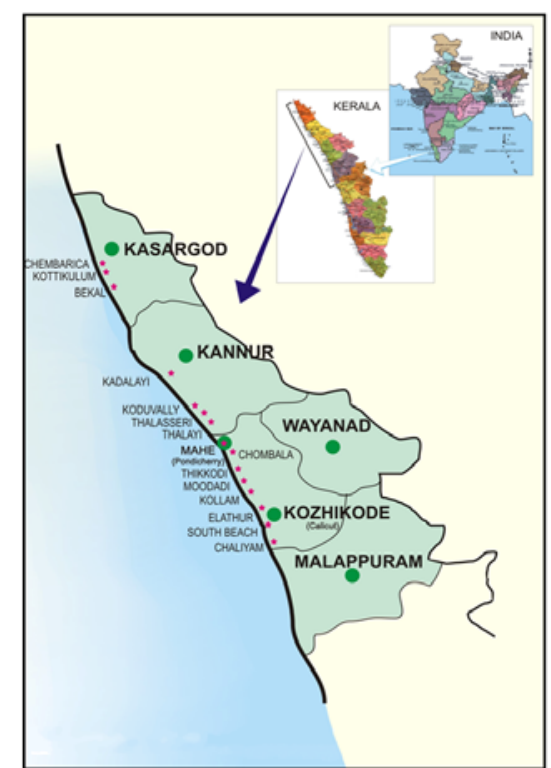

Figure 1 Northern Kerala, showing important green mussel areas and landing centers

Kuriakose and Nair (1976) and Siddall (1980). The ecology, biology, reproduction, settlement and growth of $P$. viridis has been detailed by Seed (1969), Shafee (1976), Narasimham (1980, 1981), Walter (1982), 
Chatterji et al. (1984), Vakily (1989, 1992), Alfaro (2006a, b) and Laxmilatha and Sivadasan (2007a, b).

The culture potential of the green mussel has been extensively investigated by Choo(1974), Qasim et al. (1977), Parulekar et al. (1982), Chatterji et al. (1984), Coeroli et al. (1984), Kuriakose et al. (1988), Appukkuttan et al. (1998) and Laxmilatha et al. (1996, 2001, 2009). Induced spawning, egg and larval development and spat production in hatchery have been carried out by Tan (1975), and Laxmilatha et al. (2011). Earlier reports on the green mussel fishery, biology and spat settlement are by Kuriakose et al. (1984), Selvaraj (1988), Appukuttan et al. (2001), Thomas et al. (2002) and Laxmilatha and Sivadasan (2007a).

Reproductive behavior of the green lipped mussel $P$. canaliculus has been described by Buchanan (2001) and Alfaro et al. (2001, 2003). Settlement and recruitment patterns in Mytilus galloprovincialis and $M$. canaliculus have been detailed by Peteiro et al. (2007) and Phillips (2007). Small scale settlement pattern, spatial variability in reproductive behavior, spatial and temporal variability in density and distribution of mussel larvae and spat have been described by Alfaro and Jeffs (2002), Alfaro et al. (2004), Erlandsson et al. (2005) and Porri et al. (2006 a, b, 2008).

However, the unique green mussel fishery of India has not been described in detail earlier although it has existed for decades. A review of the special features of the green mussel fishery along the south west coast of India, the spat settlement pattern, its increasing significance to the rapidly expanding mussel farming sector, and present and future management perspectives are presented.

\section{Materials and Methods}

The major green mussel beds along the South west coast are South beach, Chaliyam, Elathur, Kollam, Moodadi, Thikkodi, Chombala, Mahe, Thalasseri, Thalayi, Koduvally, Kadalayi, Chembarica, Kottikulum, and Bekal. The mussels are landed at eight major centers viz., South beach / Chaliyam, Elathur / Kollam, Moodadi/Thikkodi, Mahe, Thalassery/Thalai, Chombala Koduvally, Kadalai. The mussel landings data from the eight centers were collected at weekly intervals, by recording the number of canoes / "catamarans" (made by tying up 3 wooden logs) and number of mussel pickers. Usually 2-3 pickers go out in a small canoe/ catamaran and return with their individual collection of mussels tied in a nylon bag around their waist or heaped in the canoe. Each picker was considered as a single unit and the catch per unit effort (CPUE) is the catch landed per mussel picker in kilograms. The monthly landings from the canoes operated at each center were raised and the annual mussel production was estimated. The catch effort data of the green mussel landings at the eight major landing centers was estimated from 2003 to 2008. The monthly and annual trends in production were analyzed for the major centers. The catch data and price structure for the green mussel for the period 1996-2002 was collected from the annual reports of Central Marine Fisheries Research Institute (CMFRI Annual reports 1995-2002) for analyzing the fishery trend during the entire period from 1996-2008.

\section{Results}

\subsection{Mussel beds}

The major mussel beds along the South west coast are distributed across three districts of Kerala and in Mahe (Union Territory of Pondicherry) (Figure 1 and Figure $2 \mathrm{~A}-\mathrm{H})$. The mussel beds in Kozhikode (Calicut) district are Chombala, Thikkodi, Moodadi, Kollam, Elathur, South beach and Chaliyam, constituting about 435 ha. Mussel bed off Mahe (Pondicherry) constitutes nearly 20 ha. The major mussel beds in Kannur district are along Kadalayi, Koduvally, Thalasseri and Thalayi, constituting 125 ha. In Kasargod district, the mussel beds are off Chembarica, Kottikulum, and Bekal constituting 40 ha. The total area of mussel beds along the Malabar Coast constitutes 620 ha in area. Spat settlement occurs on lateritic formations along South beach, Chaliyam, Elathur, Kollam, Moodadi and Thikkodi. Granite rocks are observed in Chembarika, Kottikulum, Bekal, Kadalayi, Koduvally, Thalasseri, Thalayi, Mahe and, Chombala.

The size range contributing to the green mussel fishery is $40-100 \mathrm{~mm}$. The green mussels mature at $45 \mathrm{~mm}$ and they attain the size of $60-70 \mathrm{~mm}$ by end of one year. The mussels are in mature condition during June - August. Spat fall begins with the onset of monsoon (June-August) when breeding and spawning occurs. Spat settlement occurs during August to November, sometimes extending up to December during prolonged monsoon. 


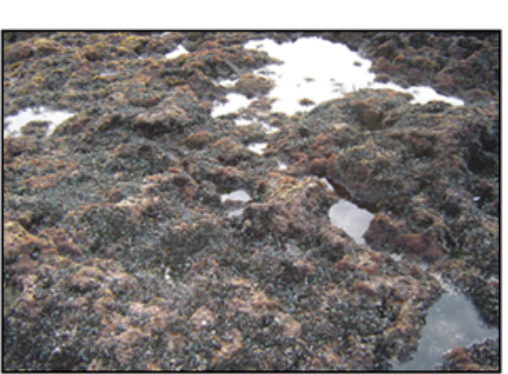

A

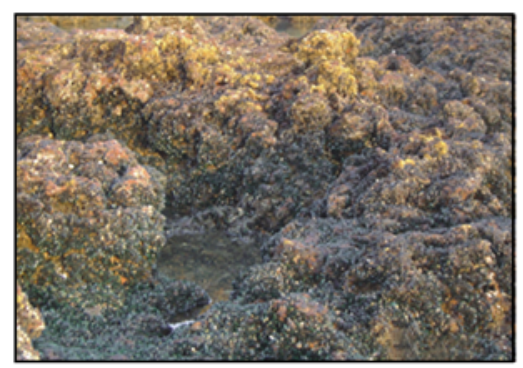

$\mathrm{D}$

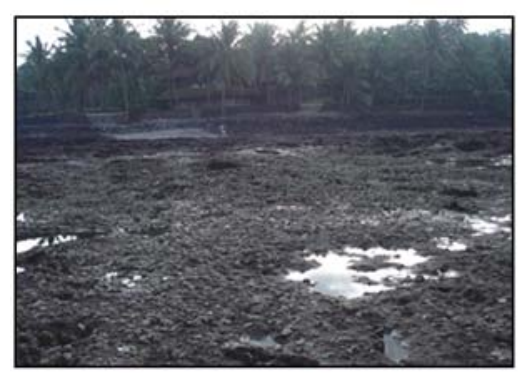

G

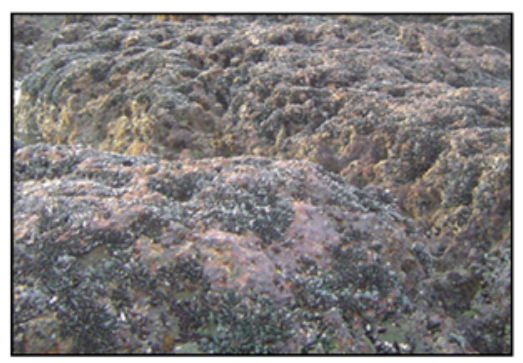

B

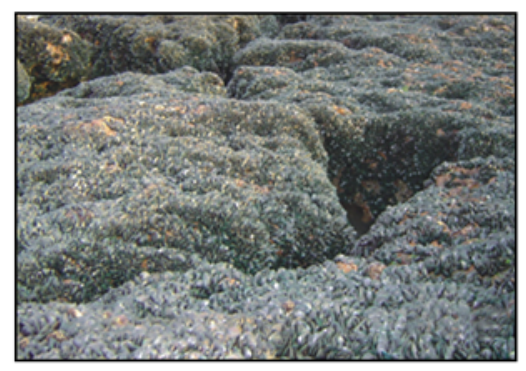

E

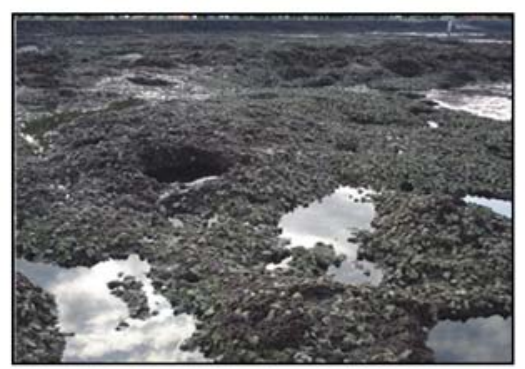

H

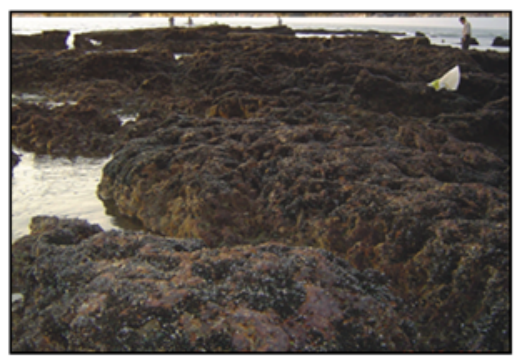

C

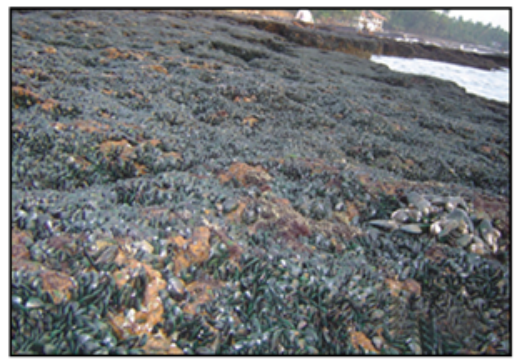

F

Figure 2 A - H. Green mussel beds and settlement

\subsection{The green mussel fishery}

The green mussel fishery along the Malabar Coast is an activity independent of the other marine fishery activities of the coast. The mussel pickers are an exclusive coastal community engaged in the exploitation of this sessile resource and 1551 persons are involved in mussel picking. The green mussel fishery begins from mid August or September onwards and lasts up to mid June. The fishery stops during the South West monsoon (June -August). Mussel picking usually begins in the early hours from 0700 hours and last for 4-5 hours. Picking is generally done during low tide, on bright sunny days when the water is clear. Pickers dive down to the mussel beds and use chisel or knife to scrape off the mussels from the intertidal rocks. The depth ranges from 0.5 to $10 \mathrm{~m}$. The pickers stock the picked mussels in nylon bags tied around their waists (Figure 3: A). In most centers, the 2-3 pickers go out in a small canoe and return with their individual collection heaped in the canoe, while in Thikkodi, the pickers use "catamarans" (made by tying up 3 wooden logs) to reach the mussel beds (Figure 3: A). The fishing duration varies depending on the demand for the mussel and the availability of the particular size range. The size of the mussels contributing to the fishery ranges from 50-100 mm. Each picker harvests about $65 \mathrm{Kg}$, known as one "Maal" / day (Figure 3: A, B). The mussels are then auctioned to the local agents. A gunny bag of picked mussel contains nearly 100-120 Kg, which fetches INR $700-1100$ (€ 11.38-17.89) during the peak season. In the local market, about 80 mm size mussels are sold at INR 80/- (€ 1.30) per 100 mussels. The price varies with size of the mussels and availability of other food fishes.

The special feature of the green mussel fishery of Malabar is the exclusive spread / distribution of the mussel beds along the coast of North Kerala, West coast of India. It extends from Kozhikode (Calicut) to 


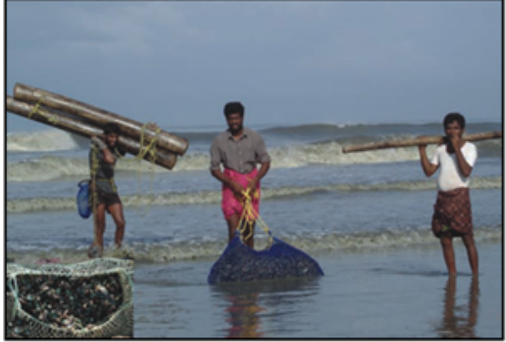

A

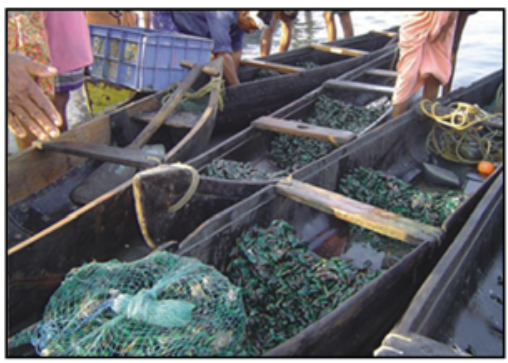

D

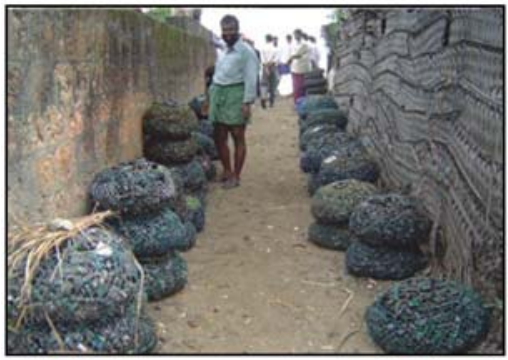

G

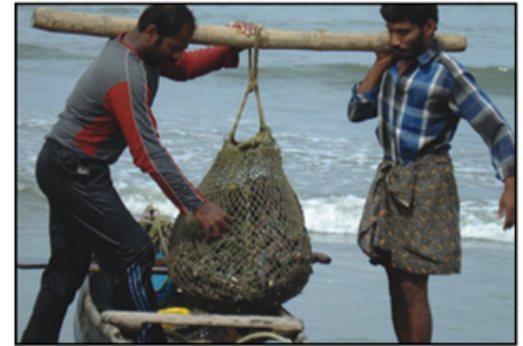

B

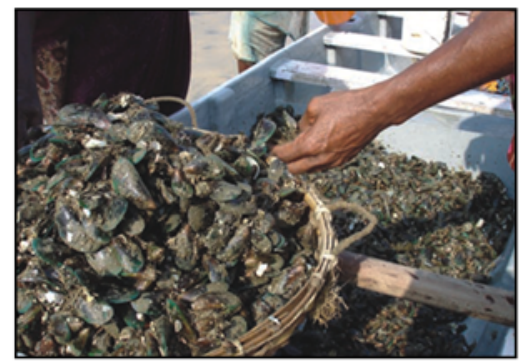

E

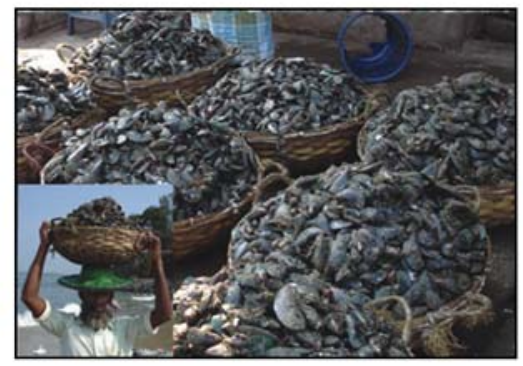

$\mathrm{H}$

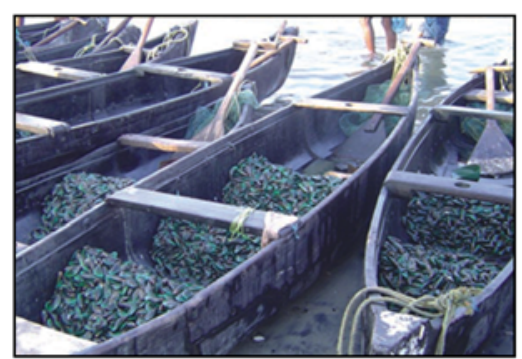

$\mathrm{C}$

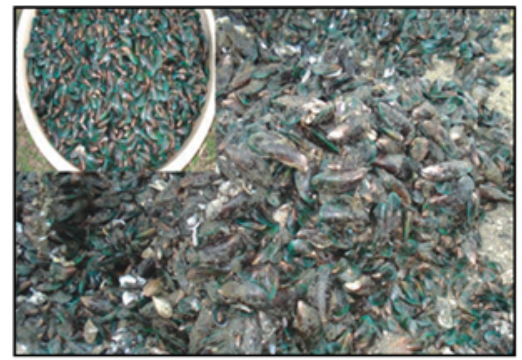

F

Figure $3 \mathrm{~A}-\mathrm{H}$. Mussel fishing activities

Kasargod and therefore forms the "Green mussel zone of India". Mussel pickers form an exclusive coastal community, who are not organized but sustain the fishery through self imposed closure of the fishery during the monsoon months. The green mussel contributes to the cuisine of North Kerala and fetches revenue of $€ 90,885$ (INR 56, 34,870/-) annually, contributing to the total marine fish production.

The estimated total production of the green mussel along the Malabar Coast during the period 1996-2008 was 89,593 $\mathrm{t}$ (Figure 4). The average annual production was $7,466 \mathrm{t}$. The total effort was 15 , 83,639 (man days) and the average annual catch per mussel picker was $56.6 \mathrm{Kg}$. The highest production was recorded during 2006 at $14,835 \mathrm{t}$ and the total effort expended was 23,325 (man days). The CPUE was $63.6 \mathrm{Kg}$. The lowest production was recorded during 1998 at 3,408 $t$ although the effort was high at 71051. The CPUE was $48 \mathrm{Kg}$. The effort has been increasing over the years especially since 2006. The year 2006 registered the highest effort $(233,257)$ and also significant increase in production (41.4\%) over the previous year. This was probably due to intense spat settlement during 2005 and increased demand for the mussels. Chaliyam, Thalasseri/Thalayi, Moodadi/ Thikkodi and Elathur / Kollam were the major centers of mussel landings (Figure 5).

The green mussel landings from the major landing

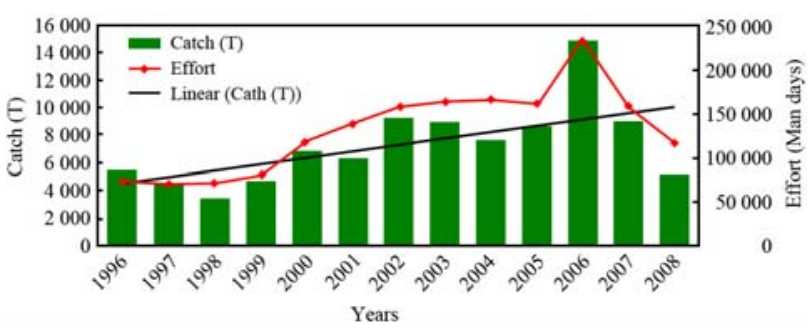

Figure 4 Trend of annual catch and effort of Perna viridis during 1996-2008 


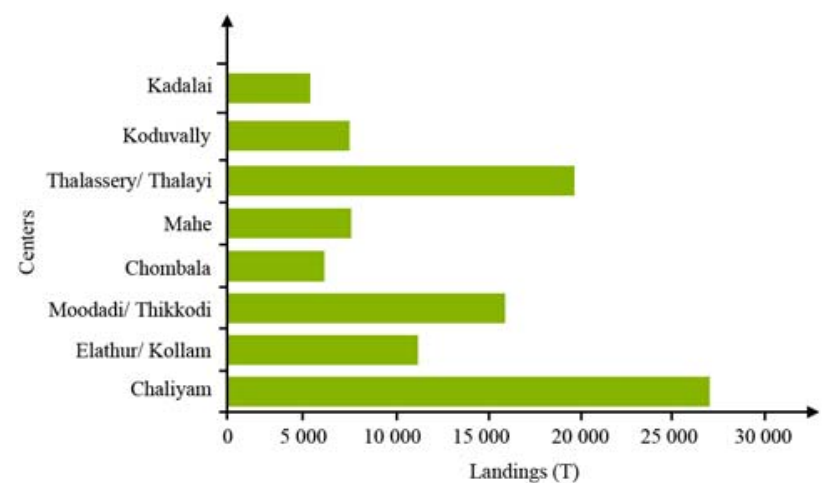

Figure 5 Landings by center, $P$. viridis during 1996-2008

centers have been analyzed in detail for 2003-2008. The estimated total production of the green mussel from the mussel beds along the Malabar Coast, during that period was 54,306 t. The average annual production was 6788 t. The total effort was 994,363 (man days) and the average annual catch per unit effort (CPUE) was $54.6 \mathrm{Kg}$. The highest production was recorded during 2006 at $14835 \mathrm{t}$ and the total effort expended was 233257. The CPUE was $63.6 \mathrm{Kg}$ per month / picker. The lowest production was recorded during 2008 at $5172 \mathrm{t}$. The CPUE was $48 \mathrm{Kg}$. The average monthly production from the mussel beds during 2003-2008 was highest during November at $12810 \mathrm{t}$ and CPUE of $63.8 \mathrm{Kg}$. The lowest average monthly production was recorded during July at $176 \mathrm{t}$ and CPUE 46.8 Kg (Figure 6).

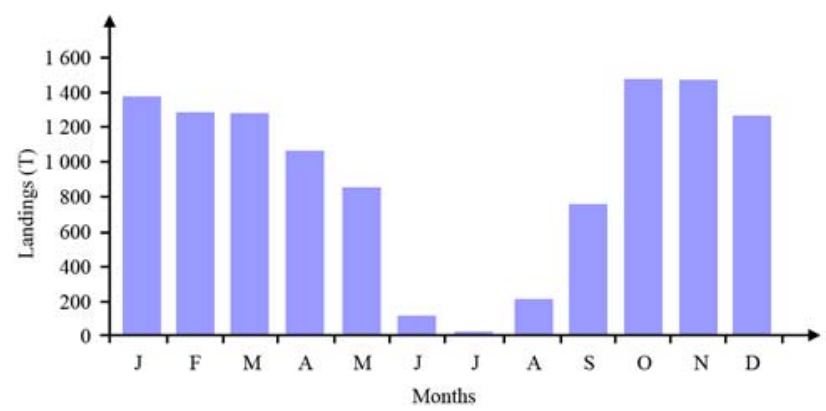

Figure 6 Average monthly landings of $P$. viridis during 2003-2008

Among the eight major mussel landing centres, Chaliyam recorded the highest production (28\%) during 2003-2008 followed by Thalasseri/Thalayi and Moodadi/Thikkodi (19\%) and Elathur/Kollam (9\%) (Table 1). Effort was also highest at Chaliyam (24\%) followed by Thalasseri/Thalayi (20\%), Moodadi/ Thikkodi (18\%). The CPUE was highest for Koduvally (71 Kg) followed by Chaliyam $(63 \mathrm{Kg})$.

\subsection{Green mussel fishery of major centers}

The catch effort details of green mussel landings at the eight major centers are given in Table 1.

Chaliyam: The average monthly production during 2003-2008 was highest during November at $388 \mathrm{t}$ and lowest in August at 20.5 t. The CPUE was highest during May at $79.2 \mathrm{Kg}$. Highest effort was expended during November.

Elathur / Kollam: The average monthly production during 2003-2008 was highest during October at $122 \mathrm{t}$ and lowest in July at $4.7 \mathrm{t}$. The CPUE was highest during September at $49 \mathrm{Kg}$. Highest effort expended was highest during October.

Moodadi / Thikkodi: The average monthly production during 2003-2008 was highest during January at $350 \mathrm{t}$ and the lowest in June at $8.6 \mathrm{t}$. The CPUE was highest during August $62.5 \mathrm{Kg}$. Highest effort was expended during October.

Chombala: The average monthly production during 2003-2008 was highest during April at $306 \mathrm{t}$ and lowest in August at $5.4 \mathrm{t}$. The CPUE was highest during October at $50 \mathrm{Kg}$. Highest effort was highest during November.

Mahe: The average monthly production during 2003-2008 was highest during October $88 \mathrm{t}$ and lowest in June at $17 \mathrm{t}$. The CPUE was highest during August at $66.5 \mathrm{Kg}$. Highest effort was expended during October.

Thalasseri / Thalayi: The average monthly production during 2003-2008 was highest during November at $249 \mathrm{t}$ and lowest in June at $35 \mathrm{t}$. The CPUE was highest during November at $75.8 \mathrm{Kg}$. Highest effort was expended during October.

Koduvally: The average monthly production during 2003-2008 was highest during April at $135 \mathrm{t}$ and lowest in July at $1.5 \mathrm{t}$ The CPUE was highest during April at $168.2 \mathrm{Kg}$. Highest effort was expended during November.

Kadalayi: The average monthly production during 2002-2008 was highest during March at $87 \mathrm{t}$ and lowest in June at $3.7 \mathrm{t}$. The CPUE was highest during January.

\subsection{Price structure}

The fresh mussels are sold locally; usually shell-on by 
numbers or weight. The mussels are brought to the local fish markets in gunny bags or plastic crates by local transport (bicycles/auto rickshaws). Cycles loads of mussels are also taken to interior areas for direct marketing in residential areas. In some areas, shucked meat is also sold. In whole of North Kerala, mussel meat is considered a delicacy and is part of the cuisine for all festive occasions. The mussel meat is consumed without depurating. Mussels form an important item in the daily menu in most households of North Kerala. The fresh mussel meat is prepared in various traditional forms and delicacies like 'ari kaduka' (rice mussel), mussel stew, and mussel fried rice and mussel biriyani. Processed products such as dried and smoked mussel meat, marinated mussel meat, mussel meat pickle, mussel meat chutney powder, canned mussel meat and ready-to-serve fried mussel meat are also available in the market. The shell finds limited use in the lime industry.

The price of the picked mussels depends upon the size, demand, season and non-availability of other food fishes. The average price for $100 \mathrm{Kg}$ of shell-on mussels during 1996-2008 was $€ 9.9$ (INR 617). The average price of $100 \mathrm{Kg}$ of shell-on green mussel ranged from $€ 5.89$ (INR 365) in 1996 to a high of $€$ 17.83 (INR 1107) in 2008 (Figure 7). The highest price $100 \mathrm{Kg}$ shell-on mussel was recorded during 2008 at $€ 21.37$ (INR 1325) at Moodadi / Thikkodi landing centre and lowest in 1996 at $€ 3.6$ (INR 223) at Mahe landing centre. The highest average price for $100 \mathrm{Kg}$ shell mussel was recorded for Kadalayi landing centre at $€ 10.9$ (INR 674). However, Kadalayi became a major landing centre since 2002 only. In 2008, the mussel price increased due to high demand but low production and the highest average price was recorded at Moodadi / Thikkodi landing centre at $€ 21.37$ (INR 1325) and the lowest at Chombala landing centre at $€ 9.56$ (\$593). Over the

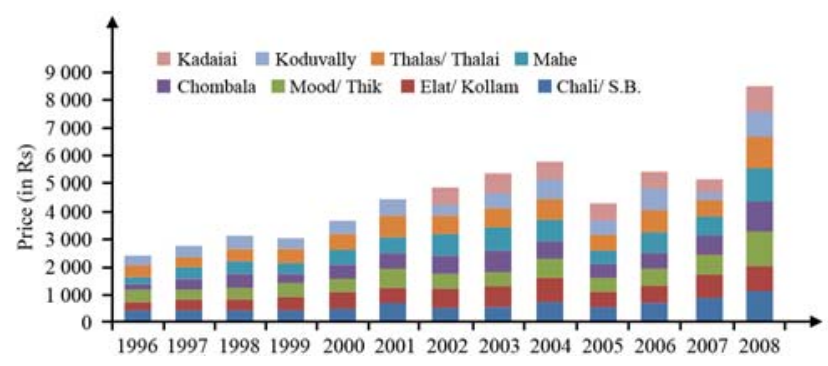

Figure 7 Price structure of $P$. viridis at major centers during 1996-2008 years, the price of green mussel has increased tremendously due to increase in demand.

\section{Discussion}

The green mussel is the only commercially important marine bivalve that forms a significant fishery in the Malabar Coast. Its extensive distribution from Bekal in Kasargod district down to South Beach in Calicut district makes it very unique and is therefore, known as the "green mussel zone of India". The green mussel fishery is self regulated. The mussel pickers stop mussel picking for 45 days during the South West Monsoon that prevails from May to July but sometimes extends up to September. It is difficult to dive and pick mussels during this season due to the turbulence and strong currents. The spawning and spat settlement also takes place during the monsoon season. The pickers resume mussel picking in mid August. The peak mussel landings occur during the post monsoon season (September to May) after the self imposed control on mussel picking during the monsoon months (Kuriakose et al., 1984; Laxmilatha and Sivadasan, 2007a).

The only estimate of green mussel production has been given by Kuriakose et al. (1988). They estimated the production, total effort (man days) and catch per unit effort for the green mussel for the years 1981-1984 at 8,715 t, 169969 and $551.7 \mathrm{Kg}$. respectively The average annual production was $2405 \mathrm{t}$ (Kuriakose et al., 1988). The production has thus increased by $90 \%$ over the 20 year period. Effort also has increased by $89 \%$. Moodadi-Thikkodi centre has traditionally been the most important landing centre (Kuriakose et al., 1988). The number of mussel pickers reported as 325 during 1981-1984 has now increased to 1551. This has been due to increased awareness and consumption of mussels and increased income generated as a result of increased demand for the green mussel. The annual production of $P$. viridis during the 13-year period was consistent except for the steep increase during 2006. This was in consonance with the regular and steady settlement of spat along the coast and consequent recruitment to the fishery. The spat settlement intensity and pattern of green mussel is influenced by the annual rainfall (Laxmilatha and Sivadasan, 2007a). The spawning cycles are dependent on the onset of the SW monsoon. In $P$. viridis, major spawning occurs during June to 
September with settlement from August to December. Spatial variation in size specific reproductive output could also have important consequences for recruitment as has been described for $P$. canaliculus and M. californianus (Alfaro et al., 2003; Phillips, 2007). Settlement occurs at low intensities throughout the year and intense settlement occurs during post monsoon (Kuriakose et al., 1984; Hunt and Scheibling, 1996).

The green mussel is also a favored candidate for farming and has been very well domesticated in the estuaries of Malabar. Mussel farming is carried out in estuaries when high saline conditions prevail from October to April. Suspended rope culture on racks is most popular but in certain low, intertidal areas, bottom culture is also practiced (Kuriakose et al., 1988; Appukuttan et al., 1998; Laxmilatha et al., 2001; Laxmilatha et al., 2009). The estimated mussel seed biomass during November 2006 was 4541 t from Kozhikode, Kannur and Mahe. Assuming that about $15 \%$ of the estimated total is used for seeding for mussel culture in the estuaries in Malabar, 681 tones of seed would be available for farming. The total length of rope that can be seeded with this quantity of seed would be 2,72,400 m, at the rate of $2.5 \mathrm{Kg}$ seed per meter of rope. About 2724 farmers can do mussel farming at the rate of $100 \mathrm{~m}$ of seeded rope per farmer. Over 2000 farmers are expected to set up mussel farms in the next few years in Padanne, Dharmadom, Valapattanam, Mahe, Korapuzha, Kadalundi, Chaliyar and Moorad estuaries. Given this scenario, although spat settlement is highly variable from year to year, there is sufficient quantity of seed that can be used for farming. Farming in most estuaries in Malabar can be done only by December end / January when higher salinity levels suitable for farming prevail. Thus farmers faced acute shortage of seed supply for farming during 2006. This has also led to exorbitant prices for the seed ( $€ 0.16 / \mathrm{Kg}$ ). The farmers are switching over to on-bottom culture instead of the suspended (rack) culture by stocking large sized mussels $(60-70 \mathrm{~mm}$, retarded mussels of previous years' settlement) which fail to attach to ropes causing significant loss due to high rate of slippage. The mussel farming sector now faces two-fold problem in acquiring seed for farming in the estuaries. Mussel spat settlement has been highly variable and not available during the mussel farming season. The mussel pickers are unwilling to supply seed to the mussel farmers. They sort the seed picked along with adults and put it back in the mussel beds. These factors have caused severe pressure on the mussel farmers due to non-availability of adequate quantities of seed for seeding (Laxmilatha and Sivadasan, 2007b; Laxmilatha et al., 2009).

In conclusion, the green mussel fishery of the South west Coast of India has unique features which contribute to the sustainability of the fishery. The increased demand for green mussel in recent years has led to increased effort and exploitation of the green mussels. However, the fishery is self managed and sustained by the mussel pickers themselves by suspending fishing during monsoon season. The special topographic distribution of the mussel beds and the interactions of the climatic factors sustain the livelihood of several wild mussel harvesters in the region.

\section{Acknowledgements}

The author is thankful to the Director, Central Marine Fisheries Research Institute, Cochin for support in carrying out this work. The assistance rendered by V. G. Surendranathan and M. P. Sivadasan in collecting the green mussel catch and effort data from the green mussel landing centers is appreciated and acknowledged.

\section{References}

Alfaro A.C., 2006, Population dynamics of the green-lipped mussel, Perna canaliculus, at various spatial and temporal scales in northern New Zealand. Journal Experimental, Marine Biology and Ecology, 334: 294-315

http://dx.doi.org/10.1016/j.jembe.2006.02.004

Alfaro A.C., Jeffs A.G., and Creese, 2004, Bottom-drifting algal/ mussel spat associations along a sandy coastal region in northern New Zealand, Aquaculture, 241: 269-290 http://dx.doi.org/10.1016/j.aquaculture.2004.07.029

Alfaro A.C., Jeffs A.G., and Hooker S.H., 2001, Reproductive behavior of the green -lipped mussel Perna canaliculatus, in northern New Zealand, Bulletin of Marine Science, 69(3): 1095-1108

Alfaro A.C., Jeffs A.G., and Hooker S.H., 2003, Spatial variability in mussel reproductive patterns at Ninety Mile Beach, northern New Zealand, Molluscan Research, 23: 223-238 http://dx.doi.org/10.1071/MR03007

Alfaro A.C., and Jeffs A.G., 2002, Small scale mussel settlement patterns within morphologically distinct substrata at Ninety Mile Beach, Northern New Zealand, MALACOLOGIA 44(1): 1-15

Appukuttan K.K., Velayudhan T.S., Kuriakose P.S., Laxmilatha P., Kripa V., and Narasimham K.A., 1998, Farming experiments and transfer of technology of bivalve culture along Southwest coast of India, Naga ICLARM Quarterly, July - September 21 (3): 3-26

Appukuttan K.K., Mohamed K.S., Kripa V., Ashokan P.K., Anil M.K., Geeta Sasikumar, Velayudhan T.S., Laxmilatha P., Said Koya K.P., Radhakrishnan P., Mathew Joseph, Alloycious P.S., Surendranathan V.G., Sivadasan M.P., Nagaraja D., Jenni Sharma and Maruthi S. Naik, 2001, Survey of green mussel seed resources of Kerala and Karnataka, Marine Fisheries Information Service, 168:12-19

Buchanan S., 2001, Measuring reproductive condition in the green shell mussel Perna canaliculus New Zealand. Journal Marine and 
Freshwater Research, 35:859-870

http://dx.doi.org/10.1080/00288330.2001.9517048

Chatterji A., Ansari Z.A., Ingole B.S and Parulekar A.H., 1984, Growth of the green mussel, Perna viridis L., in a sea water circulating system. Aquaculture, 40: 47-55

http://dx.doi.org/10.1016/0044-8486(84)90215-1

Choo P.S., 1974, Preliminary studies on the culture of the Mussel, Mytilus viridis, Linnaeus (Mollusca, Mytilidae) In: Perna. The Malaysian Agricultural Journal 49: 514-524.

CMFRI, 1996, Annual Report 1995-1996, Central Marine Fisheries Research Institute, Cochin, 181 p.

CMFRI, 1997, Annual Report 1996-1997, Central Marine Fisheries Research Institute, Cochin, 180 p.

CMFRI 1998, Annual Report 1997-1998, Central Marine Fisheries Research Institute, Cochin, $160 \mathrm{p}$.

CMFRI, 1999, Annual Report 1998-1999, Central Marine Fisheries Research Institute, Cochin, 177 p.

CMFRI, 2000, Annual Report 1999-2000, Central Marine Fisheries Research Institute, Cochin, 164 p.

CMFRI, 2001, Annual Report 2000-2001, Central Marine Fisheries Research Institute, Cochin, 163 p.

CMFRI, 2002, Annual Report 2001-2002, Central Marine Fisheries Research Institute, Cochin, 160 p.

Coeroli M., Gaillande D., Landret J.P., and AQUACOP, 1984, Recent innovations in cultivations of molluscs in French Polynesia, Aquaculture, 39: 45-67 http://dx.doi.org/10.1016/0044-8486(84)90258-8

Erlandsson J., McQuaid C.D., and Kostylev V.E., 2005, Contrasting spatial heterogeneity of sessile organisms within mussel (Perna Perna L.) beds in relation to topographic variability. Journal of Experimental Marine Biology \& Ecology, 314: 79-97 http://dx.doi.org/10.1016/j.jembe.2004.09.010

Hunt H.L., and Scheibling R.E., 1996, Physical and biological factors influencing mussel (Mytilus trossulus, M. edulis) settlement on a wave-exposed rocky shore. Marine Ecology Progress Series, 142: 135-145 http://dx.doi.org/10.3354/meps142135

Jones S., and Alagarswami K., 1973, Mussel fishery resources of India. Proceedings of Symposium on Living Resources of the Seas. India. Special Publication: 641-647

Kuriakose P.S., and Nair N.B., 1976, The Genus Perna along the coasts of India with description of a new species, Perna indica, Aquatic Biology, 1: 25-36

Kuriakose P.S., Sivadasan M.P., and Surendranathan V.G., 1984, Fishery and resource of green mussel Perna viridis along west coast of India, Bulletin Central Marine Fisheries Research Institute, 42(1): 24-29

Kuriakose P.S., Surendranathan V.G., and Sivadasan M.P., 1988, Possibilities of green mussel culture in the southwest coast of India, Bulletin Central Marine Fisheries Research Institute, 42(2): 247-256

Laxmilatha P., and Appukuttan K.K., and Velayudhan T.S., and Girijavallabhan K. G., and Alloycious P. S., 1996, Experimental Long-line Culture of Mussels Perna indica and Perna viridis at Andakaranazhi, South India. In: The Fourth Indian Fisheries Forum, Proceedings, 24-28 November, 1996, Kochi

Laxmilatha P., and Sivadasan M.P., 2007a, Mussel seed prospecting along Malabar Coast and the influence of rainfall. Marine Fisheries Information Service, T \& E Se. No. 191: 5-8

Laxmilatha P., and Sivadasan M.P., 2007b, Growth and production of vertically and horizontally suspended mussel ropes in estuarine culture, Marine Fisheries Information Service, No. 193: p 7

Laxmilatha P., Radhakrishnan P., Jenni B., and Said Koya K.P., 2001, Feasibility of integrated bivalve farming at Pallipuram, in Vypeen Island, Cochin. Marine Fisheries Information Service T \& E Se. No. 170: p 1-3

Laxmilatha P., Thomas S., Asokan P.K., Surendranathan V.G., Sivadasan M.P., and Ramachandran N.P., 2009, Mussel farming initiatives in north Kerala, India: a case of successful adoption of technology, leading to rural livelihood transformation. Aquaculture Asia, Volume XIV No. 4, October - December, p 9-13
Laxmilatha P., Rao G.S., Pattnaik P., Nageswara Rao T., Prasada Rao M., and Biswajit Dash., 2011, Potential for the hatchery production of spat of the green mussel Perna viridis Linnaeus (1758) Aquaculture, 312: 88-94 http://dx.doi.org/10.1016/j.aquaculture.2010.12.031

Narasimham K.A., 1980, Fishery and biology of the green mussel, Perna viridis (Linnaeus). In Nayar K.N., Mahadevan S., Alagarswami K., and Sundaram P.T.M., (Eds) Coastal Aquaculture: Mussel farming, Progress and prospects. Central Marine Fisheries Research Institute, Cochin, India. pp 10-17

Narasimham K.A., 1981, Dimensional relationships and growth of Green mussel Perna viridis in Kakinada Bay. Indian Journal of Fisheries, 28(1-2): 240-248

Parulekar A.H., Dalal G.S., Ansari Z.A and Harkantra S., 1982, Environmental physiology of raft-grown Mussel in Goa India. Aquaculture 29: 83-93 http://dx.doi.org/10.1016/0044-8486(82)90035-7

Peteiro L.G., Filgueira R., Labarta U., and Fernandez-Reiriz M.J., 2007, Settlement and recruitment patterns of Mytilus galloprovincialis L. in the Ria de Ares -Betanzos NW Spain in the years 2004/2005, Aquaculture Research, 38: 957-964 http://dx.doi.org/10.1111/j.1365-2109.2007.01757.x

Phillips N.E., 2007, A spatial gradient in the reproductive output of the sea mussel, Mytilus californianus, Marine Biology, 151:1543-1550 http://dx.doi.org/10.1007/s00227-006-0592-x

Porri F., McQuaid C.D., and Radloff S., 2006a, Spatio-temporal variability of larval abundance and settlement of mussel Perna perna: differential delivery of mussels. Marine Ecology Progress Series, 315: 141-150 http://dx.doi.org/10.3354/meps315141

Porri F., McQuaid C.D., and Radloff S., 2006b, Temporal Scales of Variation in settlement and recruitment of the mussel Perna perna (Linnaeus, 1758). Journal of Experimental Marine Biology \& Ecology, 332: 178-187 http://dx.doi.org/10.1016/j.jembe.2005.11.008

Porri F., McQuaid C.D., Lawrie S.M., and Antrobus S.J., 2008, Fine scale spatial and temporal variation in settlement of the intertidal mussel Perna perna indicates differential hydrodynamic delivery of larvae to the shore, Journal of Experimental Marine Biology \& Ecology, 367: 213-218 http://dx.doi.org/10.1016/j.jembe.2008.09.026

Qasim S.Z., Parulekar A.H., Harkantare S.N., Ansari Z.B.A., and Nair A., 1977, Aquaculture of green mussel Mytilus viridis L. Cultivation on ropes from floating rafts, Indian Journal of Marine Science, 4: 189-197

Seed R., 1969, The ecology of Mytilus edulis (lamellibranchiate) on exposed rocky shores: 1. Breeding and settlement, Oecologia, 3: 227-316 http://dx.doi.org/10.1007/BF00390381 http://dx.doi.org/10.1007/BF00390380

Selvaraj V., 1988, Experimental studies on the pattern of spatfall of the green mussel at Ennore, Madras. Bulletin Central Marine Fisheries Research Institute 42(2): 264-267

Shafee M.S., 1976, Studies on the various allometric relationships in the intertidal green mussel, Perna viridis Linnaeus of Ennore estuary, Madras, Indian Journal of Fisheries, 23 (1-2): 1-9

Siddall S.E., 1980, A clarification of the genus Perna (Mytillidae). Bulletin of Marine Science 30 (4): 858-870

Thomas S., Laxmilatha P., Asokan P.K., Velaudhan T.S., Surendranathan V.G., Sivadasan M.P., and Ramachandran N.P., 2002, Mussel seed resource along Malabar coast. In: Mussel culture in Malabar: prospects and constraints. P 17-19, Published by TTC-CMFRI, Cochin

Tan W.M., 1975, Egg and larval development in the green mussel Mytilus viridis Linnaeus, The Veliger 18(2): 151-155

Vakily J.M., 1989, The biology and culture of the genus Perna, ICLARM Studies and Review, 17:1-16

Vakily J.M., 1992, Determination and comparison of bivalve growth with emphasis on Thailand and other tropical areas, ICLARM Technical report 36, pp. 125

Walter C., 1982, Reproduction and growth in the tropical mussel Perna viridis (Bivalvia) Mytilidae), Kalikasan, Philippine Journal of Biology 11: 83-97 
International Journal of Marine Science 2013, Vol.3, No.48, 408-416

http://ijms.sophiapublisher.com

Table 1 Green mussel landing details at 8 major landing centers during 2003-2008

\begin{tabular}{|c|c|c|c|c|c|c|c|c|c|c|c|c|c|c|c|c|c|c|c|c|c|c|c|c|}
\hline \multirow{2}{*}{$\begin{array}{l}\text { Landing } \\
\text { center } \\
\text { Year }\end{array}$} & \multicolumn{3}{|c|}{ Chaliyam } & \multicolumn{3}{|c|}{ Moodadi/Thikkodi } & \multicolumn{3}{|c|}{ Thalassery/Thalayi } & \multicolumn{3}{|c|}{ Koduvally } & \multicolumn{3}{|c|}{ Elathur/Kollam } & \multicolumn{3}{|c|}{ Chombala } & \multicolumn{3}{|c|}{ Mahe } & \multicolumn{3}{|c|}{ Kaldalai } \\
\hline & $\begin{array}{l}\text { Catch } \\
\text { (t) }\end{array}$ & Effort & $\begin{array}{l}\text { CPUE } \\
(\mathrm{Kg})\end{array}$ & $\begin{array}{l}\text { Catch } \\
\text { (t) }\end{array}$ & Effort & $\begin{array}{l}\text { CPUE } \\
(\mathrm{Kg})\end{array}$ & $\begin{array}{l}\text { Catch } \\
\text { (t) }\end{array}$ & Effort & $\begin{array}{l}\text { CPUE } \\
(\mathrm{Kg})\end{array}$ & $\begin{array}{l}\text { Catch } \\
\text { (t) }\end{array}$ & Effort & $\begin{array}{l}\text { CPUE } \\
(\mathrm{Kg})\end{array}$ & $\begin{array}{l}\text { Catch } \\
(\mathrm{t})\end{array}$ & Effort & $\begin{array}{l}\text { CPUE } \\
(\mathrm{Kg})\end{array}$ & $\begin{array}{l}\text { Catch } \\
\text { (t) }\end{array}$ & Effort & $\begin{array}{l}\text { CPUE } \\
(\mathrm{Kg})\end{array}$ & $\begin{array}{l}\text { Catch } \\
\text { (t) }\end{array}$ & Effort & $\begin{array}{l}\text { CPUE } \\
(\mathrm{Kg})\end{array}$ & $\begin{array}{l}\text { Catch } \\
\text { (t) }\end{array}$ & Effort & $\begin{array}{l}\text { CPUE } \\
(\mathrm{Kg}) \\
\end{array}$ \\
\hline 2003 & 1933.9 & 31930 & 60.6 & 945.3 & 18080 & 52.3 & 2254.3 & 40885 & 55.1 & 637.6 & 8913 & 71.5 & 840.5 & 17338 & 48.5 & 593.1 & 13511 & 43.9 & 828.3 & 15752 & 52.6 & 896.7 & 16551 & 54.2 \\
\hline 2004 & 1217.2 & 25533 & 47.7 & 752.2 & 20646 & 36.4 & 1949.1 & 50817 & 38.4 & 989.6 & 7028 & 140.8 & 876.8 & 23056 & 38.0 & 417.4 & 9387 & 44.5 & 693.9 & 13948 & 49.7 & 748.4 & 14422 & 51.9 \\
\hline 2005 & 2126.1 & 30064 & 70.7 & 936.5 & 17725 & 52.8 & 1503.8 & 31303 & 48.0 & 666.0 & 10007 & 66.6 & 1253.2 & 27062 & 46.3 & 516.2 & 12776 & 40.4 & 861.1 & 15354 & 56.1 & 830.1 & 16258 & 51.1 \\
\hline 2006 & 3928.7 & 52805 & 74.4 & 3799.8 & 55694 & 68.2 & 3039.5 & 45948 & 66.2 & 805.6 & 13486 & 59.7 & 953.3 & 21536 & 44.3 & 396.8 & 10540 & 37.6 & 1013.8 & 17043 & 59.5 & 897.4 & 16205 & 55.4 \\
\hline 2007 & 3759.4 & 58018 & 64.8 & 2989.1 & 44185 & 67.6 & 715.6 & 12857 & 55.7 & 108.2 & 3221 & 33.6 & 536.2 & 15735 & 34.1 & 250.7 & 8344 & 30.0 & 458.9 & 9246 & 49.6 & 214.1 & 5012 & 42.7 \\
\hline 2008 & 2157.2 & 43056 & 50.1 & 903.7 & 21308 & 42.4 & 617.7 & 15402 & 40.1 & 190.6 & 5096 & 37.4 & 621.8 & 14346 & 43.3 & 193.8 & 5874 & 33.0 & 354.8 & 7241 & 49.0 & 132.5 & 3820 & 34.7 \\
\hline Total & 15122 & 241406 & & 10327 & 177638 & & 10080 & 197212 & & 3398 & 47751 & & 5082 & 119073 & & 2368 & 60432 & & 4211 & 78584 & & 3719 & 72268 & \\
\hline Average & 2520 & 40234 & 61.4 & 1721 & 29606 & 53.3 & 1680 & 32869 & 50.6 & 566 & 7958 & 68.3 & 847 & 19845 & 42.4 & 395 & 10072 & 38.2 & 702 & 13097 & 52.8 & 620 & 12045 & 48.3 \\
\hline
\end{tabular}




\section{Reasons to publish in BioPublisher}

BioPublisher ${ }^{\circ}$ A BioScience Publishing Platform

$\star$ Peer review quickly and professionally

疋 Publish online immediately upon acceptance

$\star$ Deposit permanently and track easily

is Access free and open around the world

$\star$ Disseminate multilingual available

Submit your manuscript at: http://bio.sophiapublisher.com

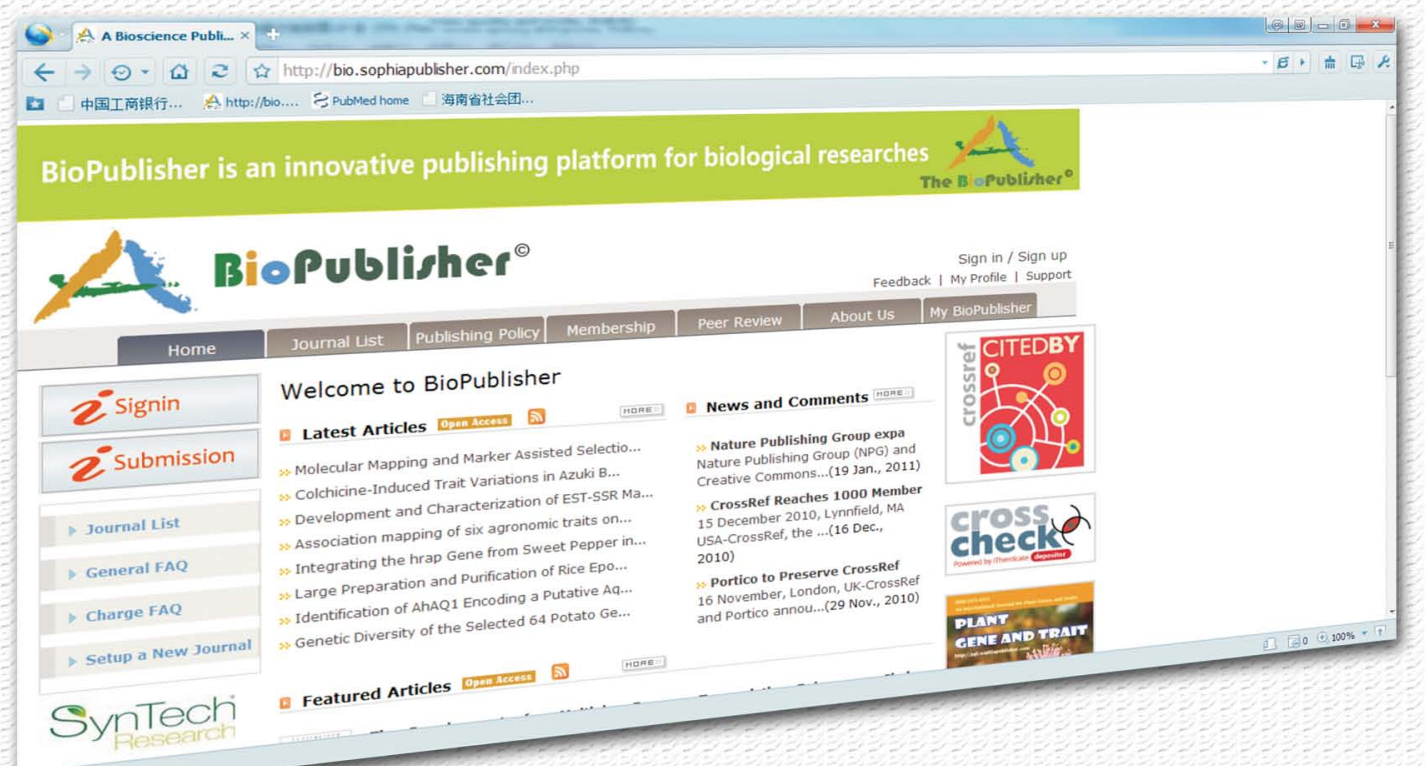

